\title{
Sowing Dates and Soybean Cultivars Influence Seed Yield, Oil and Protein Contents in Subtropical Environment
}

\author{
Clovis Pierozan Junior ${ }^{1}$, Jackson Kawakami ${ }^{2}$, Kélin Schwarz ${ }^{2}$, Renan Caldas Umburanas ${ }^{3}$, \\ Murilo Viotto Del Conte ${ }^{4} \&$ Marcelo Marques Lopes Müller ${ }^{2}$ \\ ${ }^{1}$ Federal Institute of Education Science and Technology of Paraná (IFPR), Palmas, Brazil \\ ${ }^{2}$ Midwestern State University (UNICENTRO), Guarapuava, Brazil \\ 3 “Luiz de Queiroz" College of Agriculture (ESALQ), University of São Paulo (USP), Piracicaba, Brazil \\ ${ }^{4}$ Federal University of Viçosa (UFV), Viçosa, Brazil \\ Correspondence: Clovis Pierozan Junior, Federal Institute of Education Science and Technology of Paraná (IFPR), \\ Av. Bento Munhoz da Rocha Neto S/N, PRT-280, trevo Codapar, Zip code: 85.555-000, Palmas, PR, Brazil. Tel: \\ 55-46-999-313-485. E-mail: clovis.junior@ifpr.edu.br
}

Received: February 2, 2017

Accepted: April 24, 2017

Online Published: May 15, 2017

doi:10.5539/jas.v9n6p188

URL: https://doi.org/10.5539/jas.v9n6p188

\begin{abstract}
The sowing date is the crop management practice with higher interference on soybean grain yield, although this interference is dependent on the genotype by environment interaction. This study was carried out to evaluate how soybean genotypes behave at different sowing times in a subtropical environment. We evaluated the grain yield, yield components, plant morphology and grain oil and protein content of four soybean cultivars (FPS Urano RR, BMX Apolo RR, BMX Energia RR and BRS 284) at three sowing dates (early, mid, and late sowing in 2010/2011 season) in Mid-South of Parana State, Brazil. Early cultivars at late sowing may have problems with mechanical harvest. The number of pods and grains differed among cultivars, and the cultivar "BRS 284" showed the best results. As an exception, the cultivar "BRS 284" showed yield stability among sowing dates. Higher amount of grain protein content occurs in middle and late sowing dates. The grain yield decreased with delay of sowing due to the reduction of the grains mass and in Southern Brazil is very important to assure high mass of seed to obtain high grain yields.
\end{abstract}

Keywords: Glycine max, oil, protein, grains mass, grains number

\section{Introduction}

The sowing date is possibly the main and less expensive crop management, which impacts the soybean grain yield (Popp et al., 2002; Robinson et al., 2009). In soybean crop, early sowing can increase grain yield (Wilcox \& Frankenberger, 1987) or not change it (Grau et al., 1994). For indeterminate growth habit cultivars, early sowing result in higher number of nodes per plant (Wilcox \& Frankenberger, 1987), as well as higher number of pods and grains (Perdersen \& Lauer, 2004). Early sowings can also contribute to extend the grain filling period (Bastidas et al., 2008), and therefore increase the grain yield if grain filling rate is not changed.

Late sowings can reduce grain yield due to various factors, such as: (1) low temperatures during the grain filling which can reduce the pod set and the growth of formed grains (Thomas \& Raper, 1978; Gibson \& Mullen, 1996); (2) reduction of vegetative period due to high temperatures at initial plant development that can cause low plant growth and consequently lower number of leaves and viable nodes per area (Board \& Harville, 1996; Ball et al., 2000); and (3) reduction of grain filling period due to short photoperiod (Mayor et al., 1975; Kantolic \& Slafer, 2001; Han et al., 2006).

In subtropical environment, i.e. south Brazil, it is very common the adoption of double annual cropping system by growers with winter cereals, like wheat and barley, sowed on autumn. This management delays soybean sowing, towards the end of spring.

The soybean grain yield is determined by the number of grains per area and by the grain mass, and these yield components are influenced by environmental conditions, management practices and cultivars (Mandal et al., 2009). The yield potential is, possibly, increased when there is high number of nodes, serving as a local for 
reproductive development, and when are long the flowering period, the pods formation period and the grain filling period (Bastidas et al., 2008). The amount of oil and proteins of soybean grains can also vary according to environment (Bianculli et al., 2016), and genotype (Jin et al., 2010; Rincker et al., 2014).

All factors cited can suffer high or low interference of the environment, and the grain yield of the soybean crop is the result of the interaction between genotype and environment (Liu \& Herbert, 2000). According to Lin and Binns (1994), the characteristic of a cultivar that has low variation in grain yield along various cropping years, in different environments is named stability, which can assure a high security to the grain yield. Grain yield stability is a desirable characteristic when cropping seasons coincide with climate prediction not favorable to crop cultivation. On the other hand, it is interesting to the growers to choose a cultivar with high yield potential (Metz et al., 1982), being this practice used for most soybean growers in South Brazil region.

Therefore, it is important to know the behavior of the yield components of different cultivars submitted to different sowing dates, becoming possible to plan and provide an optimized environment of development to determined cultivar, or even, to select cultivars that present more stable yield in years with less favorable climatic forecast. This study evaluated the plant morphology, grain yield and its components and the amount of oil and proteins of soybean grains of four soybean cultivars sowed at three dates in subtropical enviroment.

\section{Method}

\subsection{Experimental Site Descriptions}

Field experiment was carried out during growing season 2010/2011 in Guarapuava, situated in the subtropical zone of the Parana State (Maack, 2002), Brazil, $\left(25^{\circ} 23^{\prime} \mathrm{S}, 51^{\circ} 29^{\prime} \mathrm{W}\right.$, altitude 1,026 masl.). The climate of the region, according to classification of Köppen, is temperate of altitude $(\mathrm{Cfb})$.

The soil of the experimental area is classified as Oxisol (Pott et al., 2007), and the chemical characterization $(0-20 \mathrm{~cm})$ of the area, realized three months before the first sowing, revealed $\mathrm{pH}\left(\mathrm{CaCl}_{2}\right)$ of $5.2 ; 42 \mathrm{~g} \mathrm{dm}^{-3}$ of organic matter, levels of $3.98 \mathrm{cmol}_{\mathrm{c}} \mathrm{dm}^{-3}$ of $\mathrm{Ca} ; 2.04 \mathrm{cmol}_{\mathrm{c}} \mathrm{dm}^{-3}$ of $\mathrm{Mg} ; 0.18 \mathrm{cmol}_{\mathrm{c}} \mathrm{dm}^{-3}$ of K; $0.0 \mathrm{cmol}_{\mathrm{c}} \mathrm{dm}^{-3} \mathrm{of}$ $\mathrm{Al}$ and $6 \mathrm{mg} \mathrm{dm}^{-3}$ of $\mathrm{P}$, with cation exchange capacity (pH 7.0) of $9.73 \mathrm{cmol}_{\mathrm{c}} \mathrm{dm}^{-3}$ and base saturation of $62 \%$. All micro nutrients presented adequate levels and in the last four years the soil was cultivated with corn silage in the summer and oat as cover crop in winter.

\subsection{Climatic Conditions}

The climatic conditions in Guarapuava during the 2010/2011 cropping season, in general, was similar to the 10 years average. Figure 1a shows that the average temperatures during the cropping season did not differ sharply from the historical average, with exception of October, when the temperature was almost $2{ }^{\circ} \mathrm{C}$ lower than the 10 years average. The precipitation (Figure $1 \mathrm{~b}$ ) was also similar to the 10 years average, with high variation from the average only in December and January. The total solar radiation was higher than the 10 years average in October and November (Figure 1c). 


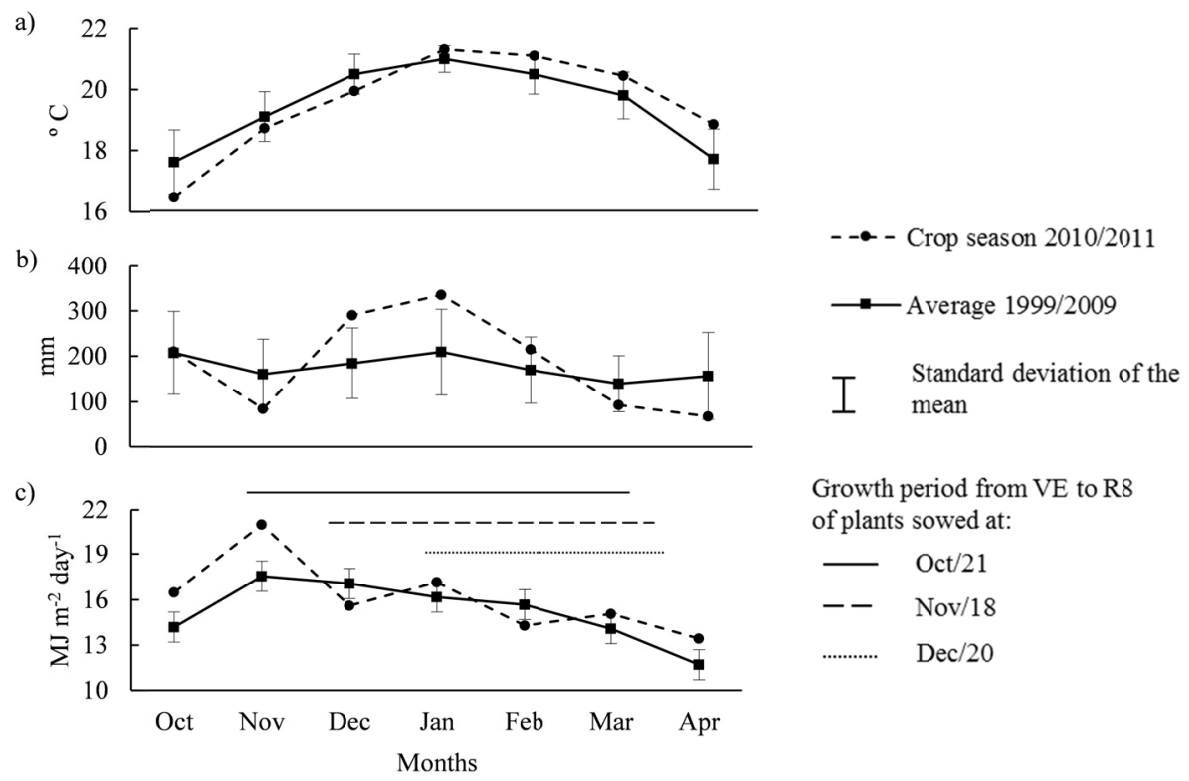

Figure 1. Climatic conditions observed at the cropping season 2010/2011 and the 10 years average in Guarapuava, PR, Brazil. a) Temperature; b) Precipitation; c) Total solar radiation

Source: Local meteorological station IAPAR (2011).

\subsection{Crop Management}

Compound fertilizer $05-25-25$ was given at $310 \mathrm{~kg} \mathrm{ha}^{-1}$ prior to sowing, totalizing $15.5 \mathrm{~kg}$ of N, $77.5 \mathrm{~kg}$ of $\mathrm{P}_{2} \mathrm{O}_{5}$ and $77.5 \mathrm{~kg}$ of $\mathrm{K}_{2} \mathrm{O}$, and at $\mathrm{V}_{4}$ growth stage (Fehr \& Caviness, 1977) leaf fertilization of cobalt and molybdenum at $2 \mathrm{~g}$ of cobalt and $30 \mathrm{~g}$ of molybdenum $\mathrm{ha}^{-1}$ was applied. The seeds were inoculated with turfs inoculants containing the strains SEMIA 5019 (Bradyrhizobium elkanii) and SEMIA 5079 (Bradyrhizobium japonicum), with 5 billion of viable cells $\mathrm{g}^{-1}$, at recommended dosage for manufacturer, and the weeds, pests and diseases were controlled according to the technical recommendations, when necessary.

\subsection{Experimental Design}

The experimental design was a split-plot arrangement with three replications (blocks). The main plots were formed by three sowing dates, being: early (10/21), mid (11/18) and late (12/20) sowings, of 2010/11 growing season. The subplots were formed by four soybean cultivars utilized in the region: (1) FPS brand "FPS Urano RR", a Maturity Group 6.2; (2) Brasmax brand "BMX Apolo RR", a Maturity Group 5.5; (3) Brasmax brand "BMX Energia RR", a Maturity Group 5.3 (4) Embrapa brand "BRS 284", a Maturity Group 6.5. Within cultivars only FPS Urano RR has determinate growth habit and the others have indeterminate growth habits. Each subplot was constituted by 4 rows, spaced by $0.4 \mathrm{~m}$ and with $11 \mathrm{~m}$ of length, totalizing $17.6 \mathrm{~m}^{2}$. Twenty seeds $\mathrm{m}^{-1}$ were sowed, totalizing a population of 500,000 plants ha ${ }^{-1}$, which at stage $V_{C} / V_{1}$ were thinned out to

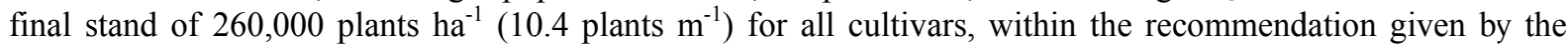
cultivars owners.

\subsection{Samping Procedures and Plant Analysis}

Plants on $2.4 \mathrm{~m}^{2}, 3 \mathrm{~m}$ at the two central lines of each subplot, were hand-harvested and counted, totalizing an average 62.4 plants per subplot, after plant maturity ( $\mathrm{R}_{8}$ growth stage).

We analyzed bottom pod height $(\mathrm{cm})$, the number of nodes on the main stem, the number of nodes on the branches, the number of total nodes of plants $\left(\mathrm{m}^{-2}\right)$, the number of branches $\left(\mathrm{m}^{-2}\right)$, the number of the pods, grains $\left(\mathrm{m}^{-2}\right)$ and the grain mass (node $\mathrm{e}^{-1}$ and $\left.\mathrm{m}^{-2}\right)$, the number of the grains $\left(\operatorname{pod}^{-1}\right)$, and the yield of the grains $\left(\mathrm{kg} \mathrm{ha}^{-1}\right)$. The moisture content of grains was corrected to $130 \mathrm{~g} \mathrm{~kg}^{-1}$.

\subsection{Oil and Proteins Analysis}

The protein determination was performed using the method of total nitrogen in plants, of the Association of Oficial Analythical Chemist- AOAC 977.02B (2006), with adaptations of Embrapa (2009) in colorimetric method, using indophenol blue (640 nm - microplate spectrophotometer model BIOTEK, EON). Two 
sub-samples of ground soybean grain were analyzed, from each repetition obtained in the field. To calculate the conversion of nitrogen in protein it was used the factor 6.25 and the percentage of protein was obtained based on dry weight basis.

The grain oil content was determined by the Soxhlet extractor with petroleum ether p.a. as solvent, according to AOAC 945.16 (AOAC, 2006). Oil concentration was expressed as percentage based on dry weight basis.

\subsection{Statistical Procedure}

The results were submitted to normality and variance homogeneity tests as well as an analysis of variance (ANOVA) by the F-test at $5 \%$ probability. When the null hypothesis was rejected, Tukey's test at $\mathrm{p} \leq 0.05$ was performed for comparison of the means of treatments.

\section{Results}

\subsection{Bottom Pod Height, Number of Pods, Seeds and Seed Mass per Node}

It was found interaction between the sowing dates and cultivars in relation to bottom pod height (Table 1). For all cultivars the bottom pod height decreased with delaying the sowing date. The cultivars BMX Apolo RR and BMX Energia RR showed higher decrease in bottom pod height with sowing delay than the other cultivars.

Interaction between sowing date and cultivar occurred in number of pods per node (Table 1). Higher values were for cultivar BRS 284, especially on plants sowed in October. The cultivar BRS 284 sowed in November and December resulted in plants with lower number of pods per node. For others cultivars the number of pods per node did not varied with the sowing date.

There was no interacation between the treatments to number of seeds per node and there was no difference among sowing dates; there was difference just among cultivars (Table 1). Cultivars FPS Urano RR, BMX Apolo RR and BMX Energia RR showed lower number of seeds per node compared to BRS 284. This pattern was also observed for mass of the seeds per node (Table 1). It was noted that the higher the number of seeds per node, the higher the seed mass per node. It was observed a decrease in the seed mass per node with sowing delay.

Table 1. Bottom pod height, number of pods per node, number of seeds per node, and seed mass per node, of four soybean cultivars sowed at three dates ${ }^{1}$

\begin{tabular}{|c|c|c|c|c|c|c|c|c|}
\hline \multirow[b]{2}{*}{ Date/cultivar } & \multicolumn{3}{|c|}{ Bottom pod height $(\mathrm{cm})$} & \multirow[b]{2}{*}{ Averages } & \multicolumn{3}{|c|}{ Pods per node $\left(\mathrm{n}^{\circ}\right)$} & \multirow[b]{2}{*}{ Averages } \\
\hline & $\begin{array}{l}\text { Oct/21 } \\
\text { (Early) }\end{array}$ & $\begin{array}{l}\text { Nov/18 } \\
\text { (Mid) }\end{array}$ & $\begin{array}{l}\text { Dec/20 } \\
\text { (Late) }\end{array}$ & & $\begin{array}{l}\text { Oct/21 } \\
\text { (Early) }\end{array}$ & $\begin{array}{l}\text { Nov/18 } \\
\text { (Mid) }\end{array}$ & $\begin{array}{l}\text { Dec/20 } \\
\text { (Late) }\end{array}$ & \\
\hline FPS Urano RR & $23.3 \mathrm{Aa}$ & 19.6 Bab & $16.4 \mathrm{Ba}$ & 19.8 & $1.57 \mathrm{Ab}$ & $1.55 \mathrm{Ab}$ & $1.51 \mathrm{Ab}$ & 1.54 \\
\hline BMX Apolo RR & $22.0 \mathrm{Aa}$ & $15.9 \mathrm{Bbc}$ & 13.1 Bab & 17.0 & $1.39 \mathrm{Ac}$ & $1.42 \mathrm{Abc}$ & $1.52 \mathrm{Ab}$ & 1.44 \\
\hline BMX Energia RR & $21.7 \mathrm{Aa}$ & $14.3 \mathrm{Bc}$ & $11.2 \mathrm{Bb}$ & 15.7 & $1.39 \mathrm{Ac}$ & $1.36 \mathrm{Ac}$ & $1.42 \mathrm{Ab}$ & 1.39 \\
\hline BRS 284 & $23.7 \mathrm{Aa}$ & $21.5 \mathrm{Aa}$ & $16.5 \mathrm{Ba}$ & 20.6 & $1.97 \mathrm{Aa}$ & $1.75 \mathrm{Ba}$ & $1.77 \mathrm{Ba}$ & 1.83 \\
\hline Averages & 22.7 & 17.8 & 14.3 & & 1.58 & 1.52 & 1.56 & \\
\hline Sowing dates (SD) & & 0.0002 & & & 0.4294 & & & \\
\hline Cultivar (C) & $\operatorname{Pr}>F$ & 0.0001 & & & 0.0001 & & & \\
\hline $\mathrm{SD} \times \mathrm{C}$ & & 0.0434 & & & 0.0115 & & & \\
\hline \multirow[b]{2}{*}{ Date/cultivar } & \multicolumn{3}{|c|}{ Seeds per node $\left(n^{\circ}\right)$} & & \multicolumn{3}{|c|}{ Seed mass per node $(\mathrm{g})$} & \\
\hline & $\begin{array}{l}\text { Oct/21 } \\
\text { (Early) }\end{array}$ & $\begin{array}{l}\text { Nov/18 } \\
\text { (Mid) }\end{array}$ & $\begin{array}{l}\mathrm{Dec} / 20 \\
\text { (Late) }\end{array}$ & Averages & $\begin{array}{l}\text { Oct/21 } \\
\text { (Early) }\end{array}$ & $\begin{array}{l}\text { Nov/18 } \\
\text { (Mid) }\end{array}$ & $\begin{array}{l}\mathrm{Dec} / 20 \\
\text { (Late) }\end{array}$ & Averages \\
\hline FPS Urano RR & 3.19 & 2.83 & 3.11 & $3.04 \mathrm{~b}$ & 0.65 & 0.52 & 0.54 & $0.57 \mathrm{~b}$ \\
\hline BMX Apolo RR & 3.17 & 3.13 & 3.48 & $3.26 \mathrm{~b}$ & 0.62 & 0.56 & 0.58 & $0.59 \mathrm{~b}$ \\
\hline BMX Energia RR & 3.12 & 3.11 & 3.39 & $3.21 \mathrm{~b}$ & 0.68 & 0.57 & 0.58 & $0.61 \mathrm{~b}$ \\
\hline BRS 284 & 4.65 & 4.17 & 4.21 & $4.34 \mathrm{a}$ & 0.72 & 0.67 & 0.70 & $0.70 \mathrm{a}$ \\
\hline Averages & 3.53 & 3.31 & 3.55 & & $0.67 \mathrm{~A}$ & $0.58 \mathrm{~B}$ & $0.60 \mathrm{~B}$ & \\
\hline Sowing dates (SD) & & 0.2177 & & & 0.0056 & & & \\
\hline Cultivar (C) & $\operatorname{Pr}>F$ & 0.0001 & & & 0.0001 & & & \\
\hline $\mathrm{SD} \times \mathrm{C}$ & & 0.1294 & & & 0.2797 & & & \\
\hline
\end{tabular}

Note. ${ }^{1}$ Uppercase letters compare averages within lines, and lowercase in columns. Averages followed by same letter do not differ statistically by Tukey test at $5 \%$ of probability. 


\subsection{Number of Nodes on the Main Stem, on the Branches, Total and Number of the Branches}

The number of nodes on the main stem showed difference just among sowing dates, decreasing with the sowing delay. However, the number of nodes on branches and total number of nodes differed only among the cultivars, and it was not affected by sowing dates. The cultivar BMX Energia RR showed the highest number of branches and number of nodes on the branches. Cultivar BRS 284 produced lower total number of nodes due to its lower number of branches (Table 2).

Table 2. Number of nodes on the main stem, on the branches, number of branches and total number of nodes of four soybean cultivars sowed at three dates ${ }^{1}$

\begin{tabular}{|c|c|c|c|c|c|c|c|c|}
\hline \multirow[b]{2}{*}{ Date/cultivar } & \multicolumn{3}{|c|}{ Nodes on main stem (no. $\mathrm{m}^{-2}$ ) } & \multirow[b]{2}{*}{ Average } & \multicolumn{3}{|c|}{ Nodes on branches (no. $\mathrm{m}^{-2}$ ) } & \multirow[b]{2}{*}{ Average } \\
\hline & $\begin{array}{l}\text { Oct } / 21 \\
\text { (Early) }\end{array}$ & $\begin{array}{l}\text { Nov/18 } \\
\text { (Mid) }\end{array}$ & $\begin{array}{l}\text { Dec/20 } \\
\text { (Late) }\end{array}$ & & $\begin{array}{l}\text { Oct/21 } \\
\text { (Early) }\end{array}$ & $\begin{array}{l}\text { Nov/18 } \\
\text { (Mid) }\end{array}$ & $\begin{array}{l}\text { Dec/20 } \\
\text { (Late) }\end{array}$ & \\
\hline FPS Urano RR & 470 & 447 & 434 & 450 & 253 & 245 & 309 & $269 \mathrm{ab}$ \\
\hline BMX Apolo RR & 490 & 440 & 408 & 446 & 239 & 220 & 274 & $244 \mathrm{~b}$ \\
\hline BMX Energia RR & 489 & 448 & 381 & 439 & 289 & 261 & 304 & $285 \mathrm{a}$ \\
\hline BRS 284 & 495 & 483 & 438 & 472 & 109 & 104 & 163 & $125 \mathrm{c}$ \\
\hline Averages & $486 \mathrm{~A}$ & $454 \mathrm{~A}$ & $415 \mathrm{~B}$ & & 222 & 207 & 263 & \\
\hline Sowing dates (SD) & & 0.0065 & & & 0.1075 & & & \\
\hline Cultivar (C) & $\operatorname{Pr}>F$ & 0.4606 & & & 0.0001 & & & \\
\hline $\mathrm{SD} \times \mathrm{C}$ & & 0.8375 & & & 0.9169 & & & \\
\hline \multirow[b]{2}{*}{ Date/cultivar } & \multicolumn{3}{|c|}{ Branches (no. $\mathrm{m}^{-2}$ ) } & & \multicolumn{3}{|c|}{ Nodes per area $\left(\right.$ no. $\left.\mathrm{m}^{-2}\right)$} & \\
\hline & $\begin{array}{l}\text { Oct/21 } \\
\text { (Early) }\end{array}$ & $\begin{array}{l}\text { Nov/18 } \\
\text { (Mid) }\end{array}$ & $\begin{array}{l}\text { Dec/20 } \\
\text { (Late) }\end{array}$ & Averages & $\begin{array}{l}\text { Oct/21 } \\
\text { (Early) }\end{array}$ & $\begin{array}{l}\text { Nov/18 } \\
\text { (Mid) }\end{array}$ & $\begin{array}{l}\text { Dec/20 } \\
\text { (Late) }\end{array}$ & Averages \\
\hline FPS Urano RR & 100 & 94 & 121 & $105 \mathrm{~b}$ & 723 & 707 & 743 & $724 \mathrm{a}$ \\
\hline BMX Apolo RR & 115 & 97 & 134 & $115 \mathrm{ab}$ & 728 & 704 & 682 & $705 a$ \\
\hline BMX Energia RR & 135 & 106 & 128 & $123 \mathrm{a}$ & 778 & 714 & 685 & $726 \mathrm{a}$ \\
\hline BRS 284 & 58 & 45 & 79 & $61 \mathrm{c}$ & 603 & 636 & 601 & $613 b$ \\
\hline Averages & $102 \mathrm{~B}$ & $85 \mathrm{C}$ & $116 \mathrm{~A}$ & & 708 & 690 & 678 & \\
\hline Sowing dates (SD) & & 0.0030 & & & 0.1990 & & & \\
\hline Cultivar (C) & $\operatorname{Pr}>\mathrm{F}$ & 0.0001 & & & 0.0001 & & & \\
\hline $\mathrm{SD} \times \mathrm{C}$ & & 0.2477 & & & 0.3255 & & & \\
\hline
\end{tabular}

Note. ${ }^{1}$ Uppercase letters compare averages within lines, and lowercase in columns. Averages followed by same letter do not differ statistically by Tukey test at $5 \%$ of probability.

\subsection{Number of Pods per Area, Seeds per Pod, Seed Yield and Mass of 100 Seeds}

The number of pods and seeds per pod did not presented interaction between the sowing dates and cultivars. For these two yield components, it was verified difference only among cultivars (Table 3 ). The interaction between the treatments was observed for mass of 100 seeds and final seed yield.

It was observed that cultivar BRS 284 and FPS Urano RR showed the highest number of pods (Table 4). For number of seeds per pod the cultivar FPS Urano RR had the lowest values. 
Table 3. Results of the analysis of variance for number of pods, number of seeds per pod, mass of 100 seeds and seed yield of four soybean cultivars sowed at three dates in Guarapuava, PR, Brazil ${ }^{1}$

\begin{tabular}{lllll}
\hline Dependet variable & $\mathrm{N}^{\mathrm{o}}$ pods $\left(\mathrm{m}^{-2}\right)$ & $\mathrm{N}^{\mathrm{o}}$ seeds $(\mathrm{pod})$ & Mass 100 seeds $(\mathrm{g})$ & ${\text { Yield }\left(\mathrm{kg} \mathrm{ha}^{-1}\right)}^{\text {Source of Variation }}$ \\
\hline Sowing dates (SD) & 0.0608 & 0.1106 & 0.0053 & 0.0007 \\
Cultivar (C) & 0.0015 & 0.0000 & 0.0000 & 0.0739 \\
$\mathrm{SD} \times \mathrm{C}$ & 0.4333 & 0.1937 & 0.0001 & 0.0211 \\
\hdashline $\mathrm{CV}^{2} 1(\%)$ & 4.46 & 4.12 & 4.44 & 3.72 \\
$\mathrm{CV}^{2} 2(\%)$ & 6.18 & 4.17 & 4.79 & 6.39
\end{tabular}

Note. ${ }^{1}$ Values of $\operatorname{Pr}>\mathrm{Fc}$ equal or lower than 0.05 and 0.01 indicate significant statistical difference at 5 and $1 \%$, respectively; ${ }^{2}$ Coefficient of variation.

Table 4. Number of pods and number of seeds per pod of four soybean cultivars sowed at three dates in Guarapuava, PR, Brazil ${ }^{1}$

\begin{tabular}{|c|c|c|c|c|c|c|c|c|}
\hline \multirow[b]{2}{*}{ Date/cultivar } & \multicolumn{3}{|c|}{ Number of pods $\left(\mathrm{m}^{-2}\right)$} & \multirow[b]{2}{*}{ Averages } & \multicolumn{3}{|c|}{ Number of seeds $\left(\operatorname{pod}^{-1}\right)$} & \multirow[b]{2}{*}{ Averages } \\
\hline & $\begin{array}{l}\text { Oct } / 21 \\
\text { (Early) }\end{array}$ & $\begin{array}{l}\text { Nov/18 } \\
\text { (Mid) }\end{array}$ & $\begin{array}{l}\text { Dec/20 } \\
\text { (Late) }\end{array}$ & & $\begin{array}{l}\text { Oct/21 } \\
\text { (Early) }\end{array}$ & $\begin{array}{l}\text { Nov/18 } \\
\text { (Mid) }\end{array}$ & $\begin{array}{l}\mathrm{Dec} / 20 \\
\text { (Late) }\end{array}$ & \\
\hline FPS Urano RR & 1132 & 1090 & 1123 & $1115 \mathrm{a}$ & 2.03 & 1.82 & 2.05 & $1.97 \mathrm{~b}$ \\
\hline BMX Apolo RR & 1011 & 997 & 1034 & $1014 \mathrm{~b}$ & 2.29 & 2.20 & 2.29 & $2.26 \mathrm{~b}$ \\
\hline BMX Energia RR & 1085 & 968 & 976 & $1010 \mathrm{~b}$ & 2.24 & 2.29 & 2.39 & $2.30 \mathrm{~b}$ \\
\hline BRS 284 & 1186 & 1114 & 1060 & $1120 \mathrm{a}$ & 2.36 & 2.38 & 2.37 & $2.37 \mathrm{a}$ \\
\hline Averages & 1103 & 1042 & 1048 & & 2.23 & 2.17 & 2.28 & \\
\hline
\end{tabular}

Note. ${ }^{1}$ Uppercase letters compare averages within lines, and lowercase in columns. Averages followed by same letter do not differ statistically by Tukey test with $5 \%$ of probability.

It was noted that in plants sowed in October, the cultivar BMX Energia RR obtained the highest seed yield among cultivars, with approximately 30\% more seed yield than cultivar BRS 284 (Figure 2a). In addition, seed yield had a high significant decrease with sowing delay for cultivars FPS Urano RR, BMX Apolo RR and BMX Energia RR, and for cultivar BRS 284, dates of sowing had no effect on final seed yield.

The mass of 100 seeds showed a sharp decrease with the delay on sowing date for cultivars FPS Urano RR, BMX Apolo RR and BMX Energia RR (Figure 2b). On the other hand, for cultivar BRS 284, the date of sowing had low effect on the mass of 100 seeds. However, cultivar BRS 284 sowed in October or November, presented lower mass of 100 seeds than other cultivars, and just when sowed in December, the mass of 100 seeds was equivalent to other cultivars, because the other cultivars decreased their 100 seed mass.
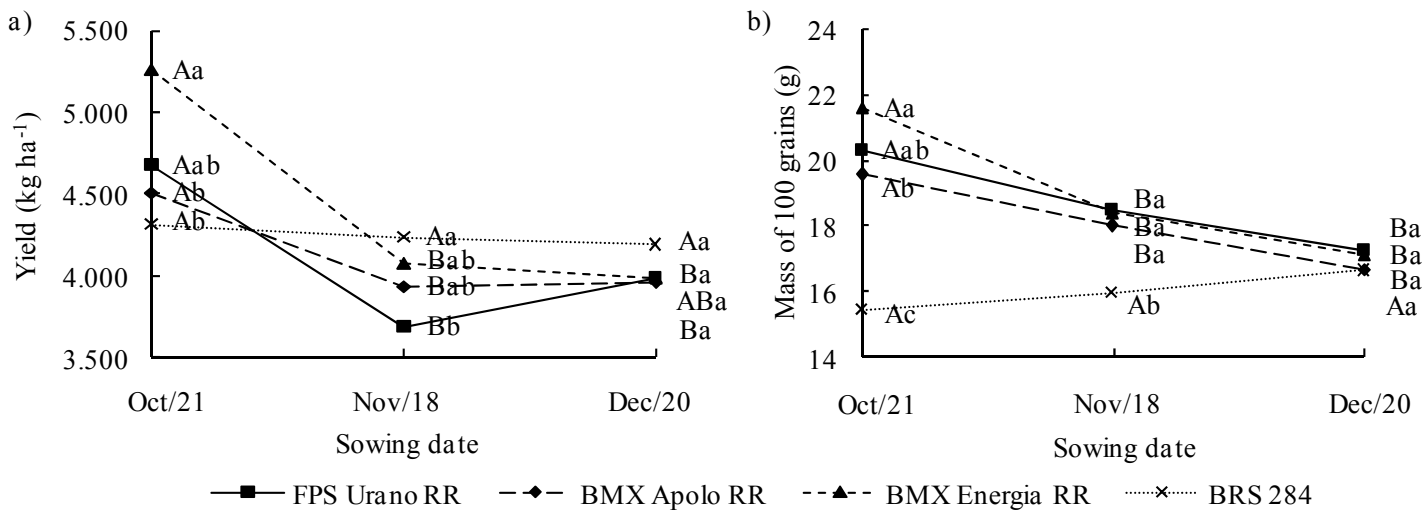

Figure 2. a) Seed yield $\left(\mathrm{kg} \mathrm{ha}^{-1}\right)$ and b) mass of 100 seeds (g) of four soybean cultivars sowed at three dates in Guarapuava, PR, Brazil. Uppercase letters compare averages of the sowing dates, and lowercase averages of the cultivars. Averages followed by same letter do not differ statistically by Tukey test at $5 \%$ of probability 


\subsection{Oil and Protein Content}

The oil content in the seeds increased with the sowing delay (Table 5). The oil content also varied among cultivars, but the range of variation was small, in which the cultivar BRS 284 had the higher content, not differing from cultivar BMX Energia.

The protein content presents interaction among sowing dates and cultivars (Table 5). In early sowing, the cultivar BMX Energia had lower protein content than when sowed in November and December. The cultivar BRS 284 had the highest protein content when sowed in November. The proteion content of other cultivars did not differed among sowing dates.

Table 5. Oil and protein content of four soybean cultivars sowed at three dates in Guarapuava, PR, Brazil ${ }^{1}$

\begin{tabular}{|c|c|c|c|c|}
\hline \multirow{2}{*}{ Cultivar } & \multicolumn{4}{|c|}{ Sowing dates } \\
\hline & Oct $/ 21$ & Nov/18 & $\mathrm{Dec} / 20$ & Averages. \\
\hline \multicolumn{5}{|l|}{ Oil content $(\%)$} \\
\hline Urano & 18,0 & 18,0 & 17,8 & $18,0 \mathrm{~b}$ \\
\hline Apolo & 18,5 & 18,2 & 17,8 & $18,1 \mathrm{~b}$ \\
\hline BMX Energia & 20,1 & 18,3 & 19,0 & $19,1 \mathrm{ab}$ \\
\hline BRS284 & 20,2 & 20,3 & 20,2 & $20,2 \mathrm{a}$ \\
\hline Average & $18,7 \mathrm{~B}$ & $18,7 \mathrm{~B}$ & $19,2 \mathrm{~A}$ & \\
\hline \multicolumn{5}{|l|}{ Protein content $(\%)$} \\
\hline Urano & $30.8 \mathrm{Aa}$ & $33.2 \mathrm{Ba}$ & $32.8 \mathrm{Aa}$ & $32.3 \mathrm{bc}$ \\
\hline Apolo & $30.9 \mathrm{Ab}$ & $32.3 \mathrm{Ba}$ & $33.4 \mathrm{Aa}$ & $30.8 \mathrm{c}$ \\
\hline BMX Energia & $31.7 \mathrm{Ab}$ & $33.2 \mathrm{Ba}$ & 35.1 Aab & $34.3 \mathrm{ab}$ \\
\hline BRS284 & $33.8 \mathrm{Ab}$ & $42.6 \mathrm{Aa}$ & $32.9 \mathrm{Ab}$ & $36.4 \mathrm{a}$ \\
\hline Average & $30.4 \mathrm{~B}$ & $35.3 \mathrm{~A}$ & $33.6 \mathrm{~A}$ & \\
\hline Significance ( $\operatorname{Pr}>F$ values) & Oil & Protein & & \\
\hline Sowing Dates (SD) & 0.0419 & 0.0149 & & \\
\hline Cultivar (C) & 0.0003 & 0.0023 & & \\
\hline $\mathrm{SD} \times \mathrm{C}$ & 0.6428 & 0.0158 & & \\
\hline
\end{tabular}

Note. ${ }^{1}$ Uppercase letters compare averages within lines, and lowercase in columns. Averages followed by same letter do not differ statistically by Tukey test with $5 \%$ of probability.

\section{Discussion}

The cultivars BMX Apolo RR and BMX Energia RR belong to maturity group 5.5 and 5.0, respectively, whereas FPS Urano RR and BRS 284 belong to maturity group 6.2 and 6.5, respectively. Therefore, it is clear that earlier cultivars result in shorter plants (Table 1). There is positive correlation between bottom pod height and plant height (Ludwing et al., 2010), and low heights of the first pod insertion, below $10 \mathrm{~cm}$ are detrimental to mechanized harvest (Motta et al., 2000). Therefore, in December sowing, the cultivar BMX Apolo RR, and mainly the cultivar BMX Energia RR, as well as others cultivars of maturity group 5.0-5.5, can have problems in mechanized harvest because of their low height of the first pod insertion. This problem can be partially solved by increasing plant density to stimulate a larger development of the plants height and consequently a higher height of the first pod insertion (Martins et al., 1999).

The fact of the cultivar BRS 284 decrease the number of pods per node with sowing delay (Table 1) can be due to flowers and pods abortion. The abortion is lower when there is larger amount of available photoassimilates, as there were in the plants sowed in October. Even with decrease of pods per node with sowing delay, the cultivar BRS 284 had the higher number of pods per node than other cultivars. In addition, the pod set can be also dependent of other factors and it is possible that the high number of pods per node be a characteristic of this cultivar (Bruening \& Egli, 2000).

The higher number of seeds per node was also of cultivar BRS 284 (Table 1), It was partly due to high number of pods per node of this cultivar.This cultivar also had the higher seed mass (Table 1), and it's because of the higher amount of seeds per node that this cultivar presented, and not because the mass of 100 seeds (Figure $2 \mathrm{~b}$ ). In this way, we can conclude that flower fixation of this cultivar is better than other cultivars. 
The number of nodes on the main stem is greater with the longer is the photoperiod (Câmara et al., 1997; Kantolic \& Slafer, 2007). This affirmation explains the results of this study, which the plants sowed in October and November, had longer photoperiod during their growth, and more nodes at main steam. The number of nodes, according to Kantolic and Slafer (2007), increased when plants were submitted for additional two hours of photoperiod during nine consecutive days between R5 and R6 growth stages. This finding supports the results of the present study as plants sowed in October and November had longer photoperiod at reproductive stages (data not shown) compared to plants sowed in December (Table 2).

The number of nodes on main stem and on branches are important parameters for explain the number of pods. According to Egli and Bruening (2006), the number of aborted pods is on average $15 \%$ higher on branches than on main stem. Therefore, we can speculate that the cultivar BRS 284 presented higher number of pods per nodes (Table 1) because this cultivar had few number of branches and number of nodes on branches, and partially compensated with high number of nodes on the main stem (Table 2). On the other hand, cultivar BRS 284 had the lowest total number of nodes (Table 2). This fact provided the BRS 284 with more pods per area, however just $10 \%$ more than cultivars BMX Energia and BMX Apolo.

The interaction between the sowing dates and cultivars for seed yield was mainly due to mass of 100 seeds (Table 3). The mass of 100 seeds also present interaction between sowing dates and cultivar. There are not significant interactions between sowing dates and cultivars for number of pods per area and number of seeds per pod, despite these two characteristics differed among cultivars.

Cultivars that had high yield had high number of pods and seeds per area (Pedersen \& Lauer, 2004; Jin et al., 2010). This result corroborates with our study for the cultivar BRS 284 sowed in December, but not for the other sowing dates, and not for other cultivars (Table 4).

According to Egli and $\mathrm{Yu}$ (1991) there is also a linear positive correlation between the crop growth rate between $\mathrm{R}_{1}-\mathrm{R}_{5}$ growth stages with the number of seeds. In the present study, during the $\mathrm{R}_{1}-\mathrm{R}_{5}$ growth stage, the cultivar BRS 284 presented the higher crop growth rate (data not shown), and probably because of this fact produced higher number of seeds per area.

Pedersen and Lauer (2004) did not verify interaction between sowing date and cultivars for number of pods per area and seeds per pod, as well as in our study. Robinson et al. (2009), in a study with sowing dates and cultivars, found important correlation between yield and number of pods according to date of sowing, where late sowing decreased the number of pods for all cultivars, reflecting negatively in seed yield. In the conditions of this study, late sowing did not reduced the number of pods per area.

The higher yield of cultivar BMX Energia RR in October sowing (Figure 2a), can be due to its greater seed filling rate, maintaining this rate constant across sowing dates (data not shown). Therefore, the higher seed yield of this cultivar when sowed in October was due to its high number of days filling the seed. The number of days of seed filling have a positive correlation with yield (Bastidas et al., 2008).

According to Kumudini et al. (2001), new cultivars of early maturity group, presented heavier seeds, but the same number of seeds, when compared with the old cultivars of the same maturity group, and attributed this fact to larger number of days and seed filling rate. The authors cited that the new cultivars of late maturity group, presented higher number of seeds per area when compared with old cultivars, but the specific mass of seeds was not different. In the present study, the cultivar BMX Energia RR is the earlier maturity cultivar group and had greater specific mass of seeds, and the cultivar BRS 284 is the later maturity cultivar group and had higher number of seeds per area.

The seed mass decrease in detriment to increase of vegetative plant growth when it were submitted to light periods of 1:30 hours superior than normal photoperiod, at seed filling period (Kantolic \& Slafer, 2005). However, in the present study, the plants sowed in October had 45 minutes more of photoperiod than plants sowed in December, at seed filling period but this did not result in reduction on seed mass (Figure 2b). The longer photoperiod probably occasioned the higher number of days of seed filling period on plants sowed in October compared to later sowing (Han et al., 2006). Calviño et al. (2003) cited that the short duration of the period of seed filling can reduce the seed mass, and this statement is supported by the results of the present study for the cultivars FPS Urano RR, BMX Apolo RR and BMX Energia RR.

High correlation between the seed yield and the seeds mass was verified. High seed yield are achieved by cultivars able to translocate high amounts of photoassimilates for the seeds, and this occurs at early sowings. However, the cultivars able to have heavy seeds and achieved high seed yields at early sowings (mainly the cultivar BMX Energia RR), had sharp decrease in its seed yields already in November sowing, suggesting the 
use of the cultivar BRS 284 which showed constant specific mass of seeds and seed yield, and despite of low yield ceiling, is an interesting option for late sowings in Southern Brazil.

Differently from other cultivars, the cultivar BRS 284 maintained constant its seed yield (Figure 2a) and its mass of 100 seeds (Figure $2 \mathrm{~b}$ ). Therefore, for all cultivars which have variation on mass of 100 seeds with sowing delay, the sowing in October, allowed higher accumulation of seeds mass, and consequently, high seed yields. Pedersen and Lauer (2004) also found positive correlation between the seed mass and seed yield in soybean.

In study realized in New York State, Cox et al. (2008) agree with the present study: the largest yields were from early sowings, suffering reduction with sowing delay. However, for the authors, the seed yield increase was due to higher number of seeds, and the mass of 100 seeds did not change with date of sowing, averaging $19.3 \mathrm{~g} 100$ seeds $^{-1}$.

In relation to interaction between sowing date and cultivar, Rao et al. (2002) cited that different environments influenced mass of 100 seeds, but, the genotypes had more influence. De Bruin and Pedersen (2008) verified in their study, one determined growth habit cultivar that practically did not alter its mass of 100 seeds, at different sowing dates or plant spacing, similarly to cultivar BRS 284 in this study, showing the importance of genotype stability. Therefore, cultivars which have light mass of seeds are not recommended in early sowings because it may restrict the final seed yield in Southern Brazil.

Heavier seeds are produced at upper fourth nodes at main stem of plants, or at branches regions close to main stem. This fact occurs because the upper portion of the plant intercept solar radiation of better quality and has higher photosynthesis rate (Illipronti Jr. et al., 2000). The cultivar BRS 284 have plenty vegetative development, which could have decreased the light in the middle and low of its canopy

Protein content is more dependent on genotype than environmental condition (Benzain \& Lane, 1986; Albrecht et al., 2008). However, we observed that the middle sowing resulted in more protein (Table 5). The temperature in a range of approximately 25 to $30^{\circ} \mathrm{C}$ in grain filling period, increases protein content of the grain (Song et al., 2016; Zuil et al., 2012). In southern of Brazil, this temperature in the grain filling occurs in soybean sowed in November, and this sowing date can provide more quality of soybean grains.

\section{Conclusion}

In Southern Brazil is very important to assure high mass of seed to obtain high seed yields in soybean crop and the cultivar BMX Energia RR is a good option for early sowing, while cultivar BRS 284 is a good option for late sowing. The November sowing provides grains with higher protein quality. Early cultivars at late sowing may have problems with mechanical harvest.

\section{Acknowledgements}

We would like to acknowledge the entities that collaborated with the authors through the provision of scholarships Fudação de Amparo à Pesquisa do Estado de São Paulo (FAPESP) process n ${ }^{\circ}$ 2013/06515-2 and 2016/06310-0, and to Conselho Nacional de Desenvolvimento Científico e Tecnológico (CNPq) process $\mathrm{n}^{\circ}$ 140209/2015-8.

\section{References}

Ball, R. A., Purcell, L. C., \& Vories, E. D. (2000). Optimizing soybean plant population for a short-season system in the southern USA. Crop Sci., 40, 757-764. https://doi.org/10.2135/cropsci2000.403757x

Bastidas, A. M., Setiyono, T. D., Dobermann, A., Cassman, K. G., Elmore, R. W., Graef, G. L., \& Specht, J. E. (2008). Soybean sowing date: The vegetative, reproductive, and agronomic impacts. Crop Sci., 48, 727-740. https://doi.org/10.2135/cropsci2006.05.0292

Bianculli, M. L., Aguirrezábal, L. A., Irujo, G. A. P., \& Echarte, M. M. (2016). Contribution of incident solar radiation on leaves and pods to soybean seed weight and composition. Eur. J. Agron., 77, 1-9. http://http://doi.org/10.1016/j.eja.2016.03.002

Board, J. E., \& Harville, B. G. (1996). Growth dynamics during the vegetative period affects yield of narrow-row, late-planted soybean. Agron. J., 88, 567-572. https://doi.org/10.2134/agronj1996.00021962008800040012x

Bruening, W. P., \& Egli, D. B. (2000). Leaf starch accumulation and seed set at phloem-isolated nodes in soybean. Field Crop. Res., 68, 113-120. https://doi.org/10.1016/S0378-4290(00)00110-6

Calviño, P. A., Sadras, V. O., \& Andrade, F. H. (2003). Development, growth and yield of late-sown soybean in the southern Pampas. Eur. J. Agron., 19, 265-275. https://doi.org/10.1016/S1161-0301(02)00050-3 
Câmara, G. M. S, Sediyama, T., Dourado-Neto, D., \& Bernardes, M. S. (1997). Influence of photoperiod and air temperature on the growth, flowering and maturation of soybean (Glycine max (L.) Merrill). Sci. Agric., 54, 149-154. https://doi.org/10.1590/S0103-90161997000300017

Cox, W. J., Shields, E., \& Cherney, J. H. (2008). Planting date and seed treatment effects on soybean in the northeastern United States. Agron. J., 100, 1662-1665. https://doi.org/10.2134/agronj2008.0015

De Bruin, J. L., \& Pedersen, P. (2008). Effect of row spacing and seeding rate on soybean yield. Agron. J., 100, 704-710. https://doi.org/10.2134/agronj2007.0106

Egli, D. B. (2005). Flowering, pod set and reproductive success in soya bean. J. Agron. Crop Sci., 191, $283-291$. https://doi.org/10.1111/j.1439-037X.2005.00171.x

Egli, D. B., \& Bruening, W. P. (2006). Temporal profiles of pod production and pod set in soybean. Eur. J. Agron., 24, 11-18. https://doi.org/10.1016/j.eja.2005.04.006

Egli, D. B., \& Yu, Z. (1991). Crop growth rate and seeds per unit area in soybean. Crop Sci., 31, 439-442. https://doi.org/10.2135/cropsci1991.0011183X003100020043x

Embrapa. (2006). Tecnologias de produção de soja: Paraná-2007 (p. 217). Londrina: Embrapa Soja.

Fehr, W. R., \& Caviness, C. E. (1977). Stages of soybean development (p. 11). Ames: Iowa State University of Science and Technology.

Gibson, L. R., \& Mullen, R. E. (1996). Soybean seed quality reductions by high day night temperatures. Crop Sci., 36, 1615-1619. https://doi.org/10.2135/cropsci1996.0011183X003600060034x

Grau, C. R., Oplinger, E. S., Adee, E. A., Hinkens, E. A., \& Martinka, M. J. (1994). Planting date and row width effect on severity of brown stem rot and soybean productivity. J. Prod. Agric., 7, $347-351$. https://doi.org/10.2134/jpa1994.0347

Han, T., Wu, C., Tong, Z., Mentreddy, R. S., Tan, K., \& Gai, J. (2006). Post flowering photoperiod regulates vegetative growth and reproductive development of soybean. Environ. Exp. Bot., 55, 120-129. https://doi.org/10.1016/j.envexpbot.2004.10.006

Illipronti Jr., R. A., Lommeni, W. M., Langerak, C., \& Struik, P. C. (2000). Time of pod set and seed position on the plant contribute to variation in quality of seeds within soybean seed lots. Neth. J. Agr. Sci., 48, 165-180. https://doi.org/10.1016/S1573-5214(00)80012-3

Jin, J., Liu, X., Wang, G., Mi, L., Shen, Z., Chen, X., \& Herbert, S. J. (2010). Agronomic and physiological contributions to the yield improvement of soybean cultivars released from 1950 to 2006 in northeast China. Field Crop. Res., 115, 116-123. https://doi.org/10.1016/j.fcr.2009.10.016

Kantolic, A. G., \& Slafer, G. A. (2001). Photoperiod sensitivity after flowering and seed number determination in indeterminate soybean cultivars. Field Crop. Res., 72, 109-118. https://doi.org/10.1016/S0378-4290(01) 00168-X

Kantolic, A. G., \& Slafer, G. A. (2005). Reproductive development and yield components in indeterminate soybean as affected by post-flowering photoperiod. Field Crop. Res., 93, 212-222. https://doi.org/10.1016/ j.fcr.2004.10.001

Kantolic, A. G., \& Slafer, G. A. (2007). Development and seed number in indeterminate soybean as affected by timing and duration of exposure to long photoperiods after flowering. Ann. Bot., 99, 925-933. https://doi.org/10.1093/aob/mcm033

Kumudini, S., Hume, D. J., \& Chu, G. (2001). Genetic improvement in short season soybeans: I. dry matter accumulation, partitioning, and leaf area duration. Crop Sci., 41, 391-398. https://oi.org/10.2135/ cropsci2001.412391x

Lin, C. S., \& Binns, M. R. (1994). Concepts and methods of analyzing regional trial data for cultivar and location selection. Plant Breed. Rev., 12, 271-297. https://doi.org/10.1002/9780470650493.ch10

Liu, X. B., \& Herbert, S. J. (2000). Some aspects of yield physiology research in soybean. J. NE. Agr. Univ., 7, 171-178. Retrieved from http://www.cqvip.com/qk/85645x/200001/6998271.html

Ludwig, M. P., Dutra, L. M. C., Lucca Filho, O. A., Zabot, L., Uhry, D., Lisboa, J. I., \& Jauer, A. (2010). Características morfológicas de cultivares de soja convencionais e Roundup ReadyTM em função da época e densidade de semeadura. Cienc. Rural., 40, 759-767. https://doi.org/10.1590/S0103-84782010000400003

Maack, R. (2002). Geografia física do Estado do Paraná (3rd ed., p. 440). Curitiba: Imprensa Oficial. 
Mandal, K. G., Hati, K. M., \& Misra, A. K. (2009). Biomass yield and energy analysis of soybean production in relation to fertilizer-NPK and organic manure. Biomass Bioenerg., 33, 1670-1679. https://doi.org/10.1016/ j.biombioe.2009.08.010

Major, D., Johnson, D., Tanner, J., \& Anderson, I. (1975). Effects of day length and temperature on soybean development. Crop Sci., 15,174-179. https://doi.org/10.2135/cropsci1975.0011183X001500020009x

Metz, G. L., Green, D. E., \& Shibles, R. M. (1982). Relationship between soybean yield in narrow rows and leaflet, canopy, and developmental characters. Crop Sci., 24, 462-547. https://doi.org/10.2135/cropsci1984. 0011183X002400030006x

Motta, I. de S. E., Braccini, A. de L., Scapim, C. A., Gonçalves, A. C. A., \& Braccini, M. do C. L. (2000). Características agronômicas e componentes da produção de sementes de soja em diferentes épocas de semeadura. Rev. Bras. Sementes., 22, 153-162. https://doi.org/10.17801/0101-3122/rbs.v22n2p153-162

Pedersen, P., \& Lauer, J. G. (2004). Response of soybean yield components to management system and planting date. Agron. J., 96, 1372-1381. https://doi.org/10.2134/agronj2004.1372

Popp, M. P., Keisling, T. C., Mcnew, R. W., Oliver, L. R., Dillon, C. R., \& Wallace, D. M. (2002). Planting date, cultivar, and tillage system effects on dryland soybean production. Agron. J., 94, 81-88. https://doi.org/10.2134/agronj2002.8100

Rao, M. S. S., Mullinix, B. G., Rangappa, M., Cebert, E., Bhagsari, A. S., Sapra, V. T., ... Dadson, R. B. (2002). Genotype $\times$ environment interactions and yield stability of food-grade soybean genotypes. Agron. J., 94, 72-80. https://doi.org/10.2134/agronj2002.0072

Robinson, A. P., Conley, S. P., Volenec, J. J., \& Santini, J. B. (2009). Analysis of high yielding, early-planted soybean in Indiana. Agron. J., 101, 131-139. https://doi.org/10.2134/agronj2008.0014x

Thomas, J. F., \& Raper Jr., C. D. (1978). Effect of day and night temperatures during floral induction on morphology of soybean. Agron. J., 70, 893-898. https://doi.org/10.2134/agronj1978.000219620070000 $60001 \mathrm{x}$

Wilcox, J. R., \& Frankenberger, E. M. (1987). Indeterminate and determinate soybean responses to planting date. Agron. J., 79, 1074-1078. https://doi.org/10.2134/agronj1987.00021962007900060025x

\section{Copyrights}

Copyright for this article is retained by the author(s), with first publication rights granted to the journal.

This is an open-access article distributed under the terms and conditions of the Creative Commons Attribution license (http://creativecommons.org/licenses/by/4.0/). 